\title{
Editorial: Special Issue on Water security and the food-water-energy nexus: drivers, responses and feedbacks at local to global scales
}

\author{
Barry Croke $^{1}$ and Graham Jewitt ${ }^{2}$ \\ ${ }^{1}$ Fenner School of Environment and Society, and Mathematical Sciences Institute, Australian National \\ University, Australia \\ ${ }^{2}$ Centre for Water Resources Research, University of KwaZulu-Natal, South Africa \\ Correspondence: Barry Croke (barry.croke@anu.edu.au) \\ Published: 1 February 2018
}

The papers presented in this special issue were part of a symposium held during the IAHS Scientific Assembly in Port Elizabeth, South Africa, in July 2017. Contributions were invited that investigated the issue of water security and more broadly the food-water-energy nexus; including investigation of water quality as well as quantity, hydro-economics, education, transboundary issues, the influence of processes operating at local to global scales, as well as those that compared conclusions drawn from local and global studies.

The papers presented in this special issue cover a wide range of topics, and have a broad geographical focus. Grigg et al. and Goomo et al. focus on the food-energy-water nexus, with Grigg et al. discussing the biophysical and socioeconomic challenges facing Pakistan, while Goomo et al. consider how to support better decisions, focusing on the Zambezi Basin. Some of the other papers focused on the water-energy part of the nexus (Cullis et al., Engström et al., and Adegun et al.). Cullis et al. present an approach to modelling the water-energy nexus to inform the planning process in the water and energy sectors. Engstrom et al. illustrate that local actions to mitigate climate change may significantly affect water resources elsewhere and Adegun et al., consider the interplay between water resources, hydropower generation and agricultural landuse.
The remaining papers have more of a focus on water security. Croke et al. focused on the impact of water and food security on livelihoods in rural India and Bangladesh; Xiaojun et al., Madrigal et al., Romashchenko et al., and Ghembreamlak et al. look at water demand and security in very different situations across the globe (China, Mexico, Ukraine and Sudan respectively); while Gusev et al., Kok et al., and Odunuga et al. focus more on agricultural systems. Gusev et al. report on modelling the effectiveness of mulch in improving soil moisture, crop yield and energy costs in Russia and Ukraine. Kok et al. discuss the potential of trade in phosphorus within Africa to address food security. Odunuga et al. discuss the potential of control measures in managing soil erosion in the Orashi River Basin in Nigeria. Finally, Yang et al. looked at the potential impact of future climate change on water resources. 